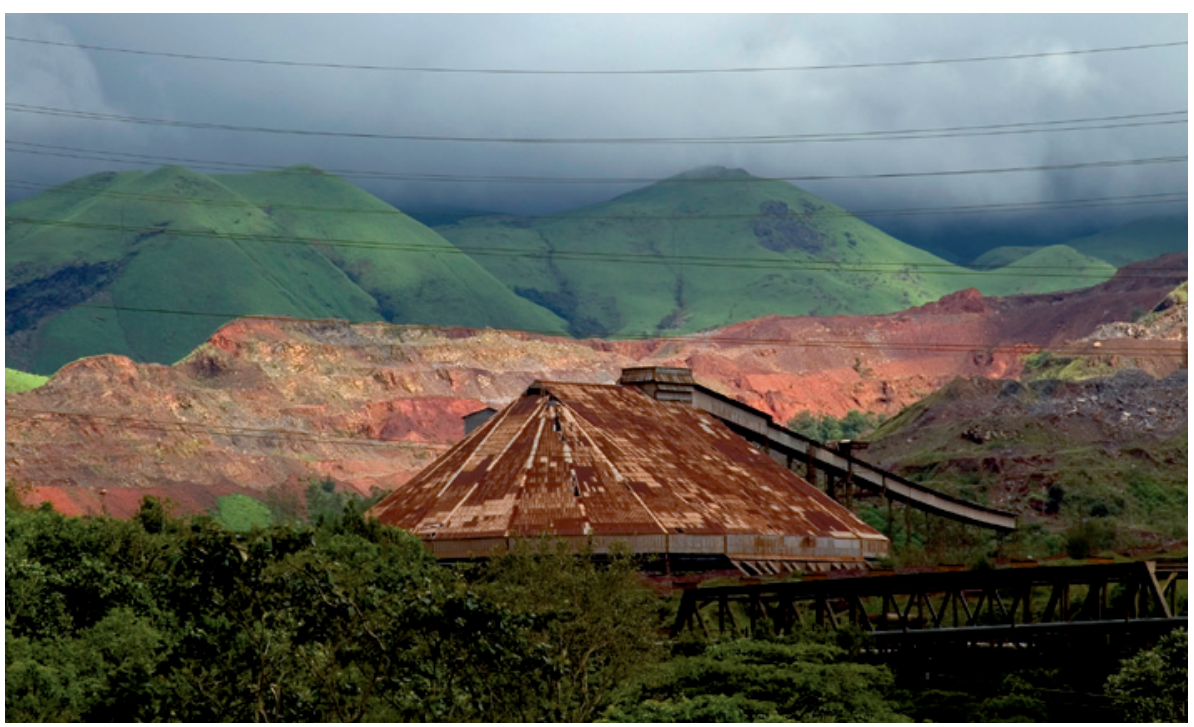

Mining in the Western Ghats region, where around one-third of India's plant and animal species are found.

\title{
CONSERVATION
}

\section{India faces uphill battle on biodiversity}

\section{Government decision to limit protection for species-rich mountains angers conservationists.}

\section{BY T. V. PADMA}

$\mathrm{I}$ ndia's Western Ghats are a tainted paradise. Running almost the length of the country's western coast, the mountain range covers just $6 \%$ of India's landmass but is home to more than $30 \%$ of its plant, fish, bird and mammal species, making it one of the world's top ten biodiversity hotspots. But the mountains also contain large mineral reserves.

The question of how to strike a balance between protecting and developing the region, home to 39 UNESCO World Heritage sites, has been troubling India. Last month, matters came to a head when ministers announced that they would accept the recommendations of a working group to cordon off more than onethird of the region and ban many industrial activities within it.

This may sound like good news, but the recommendations ran roughshod over a 2011 government-commissioned report by the Western Ghats Ecology Expert Panel. Headed by one of India's leading ecologists, Madhav Gadgil, a visiting professor at Goa University in Taleigao Plateau, the report advised classifying the entire region as ecologically sensitive.

The two groups are now at loggerheads, and the government's November decision has led to protests by conservationists, farmers and the mining and construction industries.
"There was no need for yet another report after the Gadgil committee report," says Sreedhar Ramamurthy, managing trustee of the Environics Trust, a non-governmental organization based in New Delhi. "The aim seems to be to open up more areas for development projects."

Much of the concern over the Western Ghats (see 'Protection limits') centres on the rampant, and highly polluting, illegal mining of iron ore and manganese in Goa and Karnataka states.

In 2010, environment minister Jairam Ramesh commissioned Gadgil to look at the region's ecological and industrial problems. The report, submitted in August 2011, graded

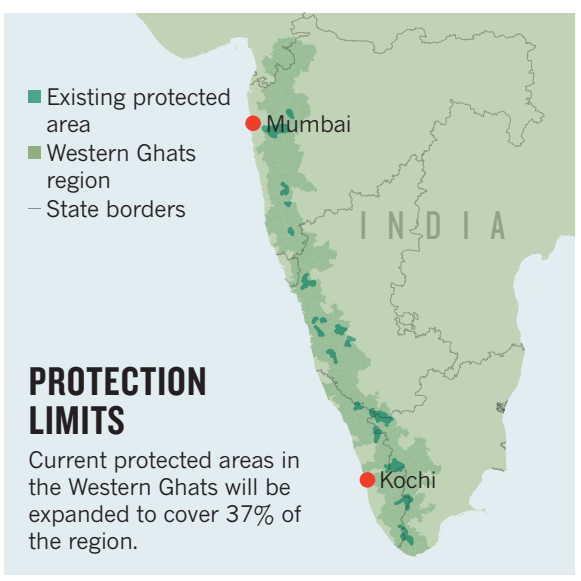

the entire Western Ghats into three zones of varying ecological sensitivity and recommended a ban on mining in the most sensitive areas.

The report came a month too late for Ramesh, who was replaced in July 2011 after rattling the powerful mining lobby by enforcing environmental standards. The whole issue was shelved until August 2012, when Ramesh's successor, Jayanthi Natarajan, commissioned a panel headed by Krishnaswamy Kasturirangan, the former chairman of India's space agency, to look again at the region.

The resulting report recommends designating just $37 \%$ of the Western Ghats as ecologically sensitive - some 60,000 square kilometres including World Heritage sites, protected areas and tiger reserves. Banned from this zone would be quarrying and mining activities, as well as other heavily polluting industries such as the manufacture of pesticides and cement.

Almost all of the remaining area (60\%) is designated as 'cultural landscape', covering villages, agriculture and non-forest plantations.

The authors acknowledge that they "deviated" from Gadgil's report by recommending prohibitions only on the most damaging activities in the most sensitive areas, and instead placed a focus on "good development". Industry bodies view the Kasturirangan report, which was accepted by the government on 16 November, as an improvement on Gadgil's.

But the 37\% demarcation has angered biodiversity experts. They say that the panel has in effect left the rest of the Western Ghats open to industrial activities. On reading a draft of the report in May, Gadgil shot off an open letter to Kasturirangan, saying that the decision is "like trying to maintain oases of diversity in a desert of ecological devastation".

In an interview with Nature, Gadgil added, "The report has arbitrarily come up with the concept of 'natural' and 'cultural' landscapes, suggesting that only 'natural' landscapes need to be protected. This has no scientific basis."

Narendra Prasad, former head of the landscape ecology division at the Salim Ali Centre for Ornithology and Natural History in Coimbatore, thinks that the Gadgil report is "more acceptable" given that it favours a "more democratic approach" and long-term sustainability.

Kasturirangan did not respond directly to Gadgil's criticism, but told Nature that issues raised by Gadgil "have already been well addressed" in his report. Government officials declined to comment.

Gadgil notes that India's 2002 Biological Diversity Act has sufficient provisions to protect the nature and people of the Western Ghats - if only the conditions were enforced. But "successive governments have done their best to scuttle them", he says. The government's acceptance of the new report is yet another step, he adds, towards "development by imposition, and conservation by imposition". 